\title{
METALLIFEROUS BLACK SHALES - A PROBABLE SOURCE OF MERCURY IN PIKE IN LAKE KOLMISOPPI, SOTKAMO, FINLAND
}

\author{
KIRSTI LOUKOLA-RUSKEENIEMI
}

\begin{abstract}
LOUKOLA-RUSKEENIEMI, KIRSTI, 1990: Metalliferous black shales - a probable source of mercury in lake Kolmisoppi, Sotkamo, Finland. Bull. Geol. Soc. Finland 62, Part 2, 167-175.

Black shale formations $20-400 \mathrm{~m}$ thick, deposited $1.96-2.10 \mathrm{Ga}$ ago and rich in carbon, sulphur and metals, are encountered in eastern Finland. They commonly contain some $0.2 \mathrm{ppm}$ mercury, but in certain localities concentrations are high due to hydrothermal addition; in the area of lake Kolmisoppi in Sotkamo there is a $\mathrm{Ni}-\mathrm{Cu}-\mathrm{Zn}$ occurrence in black shales, which contains $1.7 \mathrm{ppm}$ mercury on average and $7.5 \mathrm{ppm}$ maximum.

Compared with the background mercury concentrations in pike (Esox lucius L.) in Finnish lakes, which are generally lower than $0.5 \mathrm{ppm}$, pike in lake Kolmisoppi exhibit an anomalously high concentration of $0.96 \mathrm{ppm}$. As mercury concentrations in pike in lakes in Sotkamo vary widely, and as metal-rich black shale is one of the most readily weathered rocks in Finland, the anomaly might be due to the bedrock.
\end{abstract}

Key words: metasedimentary rocks, black shale, mercury, environmental geology, lakes, Proterozoic, lake Kolmisoppi, Sotkamo, Finland

Kirsti Loukola-Ruskeeniemi: (Academy of Finland), Geological Survey of Finland, 02150 Espoo, Finland

\section{Introduction}

Black shales were originally argillaceous sediments containing organic matter. The first comprehensive study on the chemical composition of Finnish black shales revealed that they contain elevated concentrations of mercury (Ruskeeniemi et al. 1986). Mercury is toxic and its presence in fish and other foods in concentrations close to current safety levels make it of particular concern to environmental scientists. Black shales contain other elements of environmental interest as well, like base metals, cadmium, chlorine, fluorine and selenium, but their concentrations are not reported in detail in this paper.

The present study on the metallogeny and geochemistry of black shales began in 1988 as a pro- ject of the International Geological Correlation Programme 254 (Talvitie et al. 1989, LoukolaRuskeeniemi 1989). This is a preliminary report - studies on the mercury concentrations in black shales continue, mainly for explorational purposes. The application to environmental science is an interesting by-product.

\section{Sampling and analytical methods}

Rock samples were sections of non-weathered drill core with an average length of $40 \mathrm{~cm}$, selected to represent petrographically determined black shale subtypes as homogeneously as possible.

Carbon was determined with a Leco carbon analyzer and sulphur with a Leco sulphur analyz- 
er at Geological Survey of Finland. Copper, zinc, nickel and cobalt (Fig. 6) were determined by plasma spectrometry (ICP, multi-acid extraction) at X-Ray Laboratories Ltd. (XRAL), Canada.

In a preliminary study (Ruskeeniemi et al. 1986), 180 samples were analysed for mercury by radiochemical neutron activation analysis in Reactor Laboratory of the Technical Research Centre of Finland, Espoo.

Values presented in Table 1 and in Fig. 7 were determined for purposes of the present study at XRAL. Altogether 850 samples were analysed by the cold vapour method (lower detection limit
$0.005 \mathrm{ppm}) ; 287$ samples in which the upper detection limit of $1 \mathrm{ppm}$ exceeded were reanalysed by the $\mathrm{Hg}$ assay method. Appalachian Basin Devonian black shale SDO-1 was used as analytical standard.

\section{Karelian black shales in eastern Finland}

The black shales in Finland are rarely exposed, but their distribution is known from geophysical measurements. The Karelia supergroup $(1.7-2.5 \mathrm{Ga}$ in age), which rests unconforma-

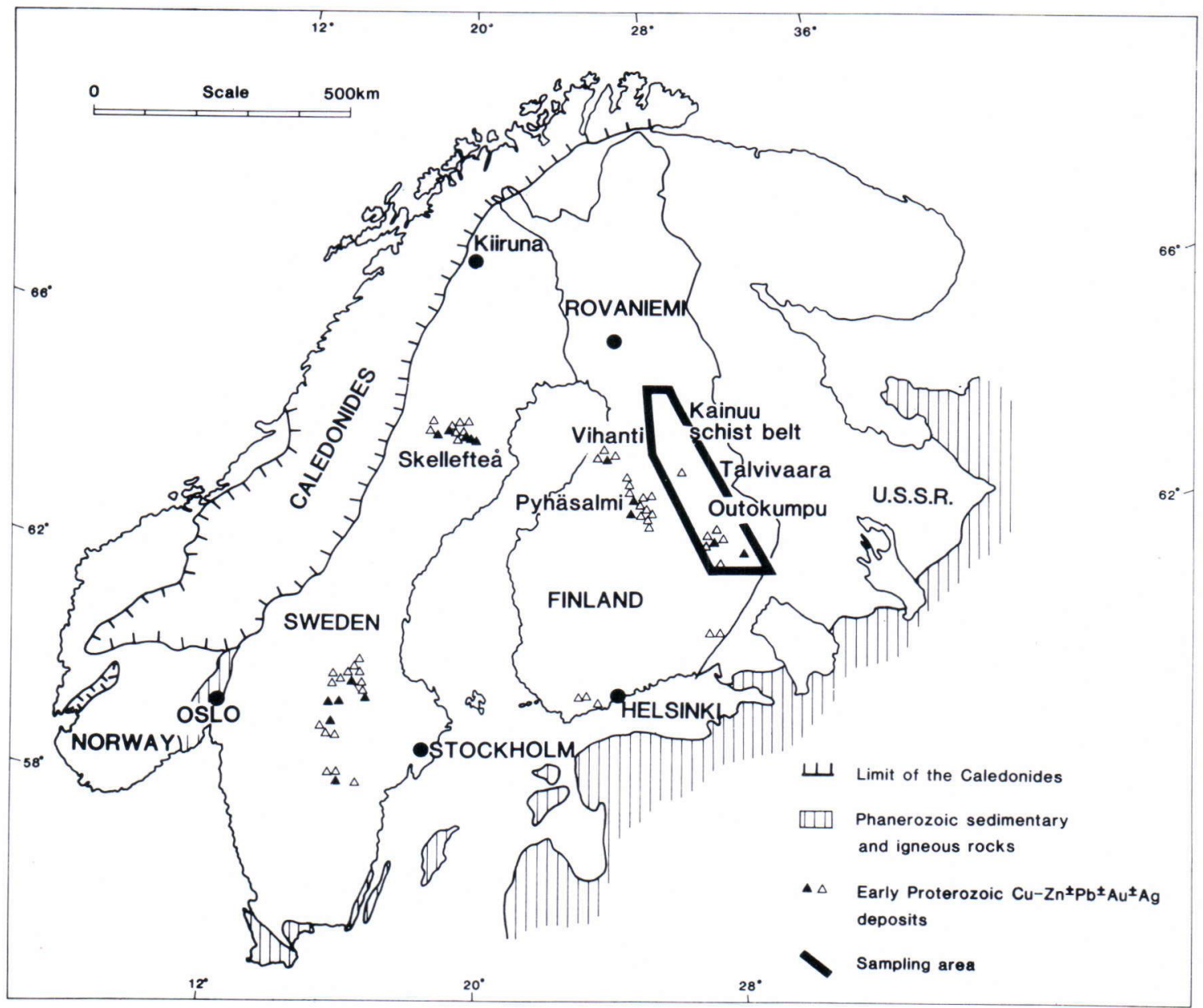

Fig. 1. General location of the study area and selected Early Proterozoic $\mathrm{Cu}+\mathrm{Zn}+-\mathrm{Pb}+-\mathrm{Au}+-\mathrm{Ag}$ ore deposits and mineralizations in the Fennoscandian shield. 


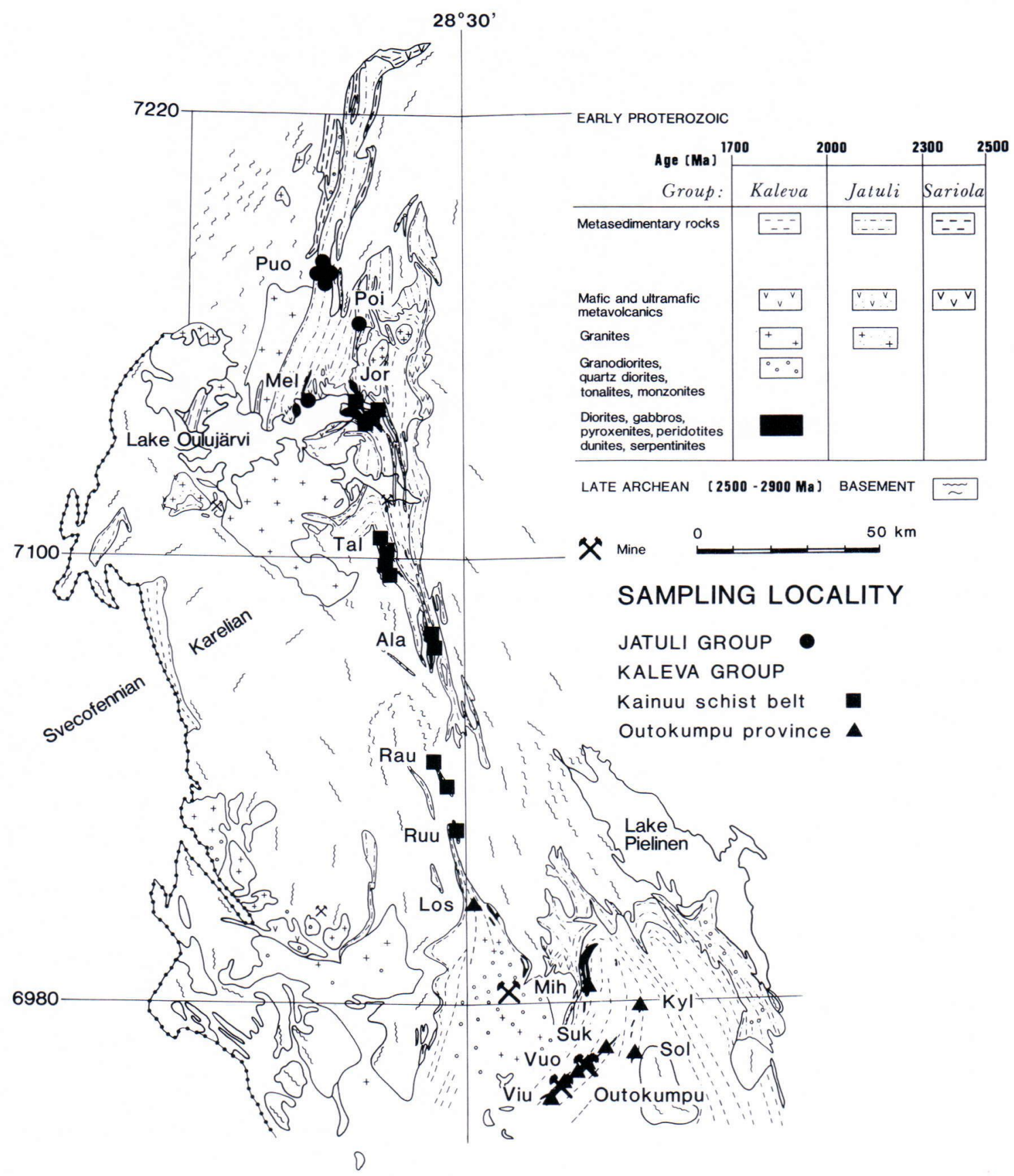

Fig. 2. Generalized geological map of the Kainuu schist belt and the Outokumpu province (modified after Luukkonen and Lukkarinen 1985). Sampling localities: Puo $=$ Puolanka, Mel $=$ Melalahti, Poi $=$ Poikkijärvi, Jor $=$ Jormua, Tal $=\mathrm{Tal}-$ vivaara (Kuusilampi and Kolmisoppi prospects), Ala = Alanen, Rau = Rautavaara (Pappilanmäki and Korpimäki targets), Ruu $=$ Ruukinsalo, Los $=$ Losomäki, Mih $=$ Mihkali, Viu $=$ Viurusuo, Vuo $=$ Vuonos mine, Suk $=$ Sukkulansalo, $\mathrm{Kyl}=$ Kylylahti, Sol $=$ Sola. 


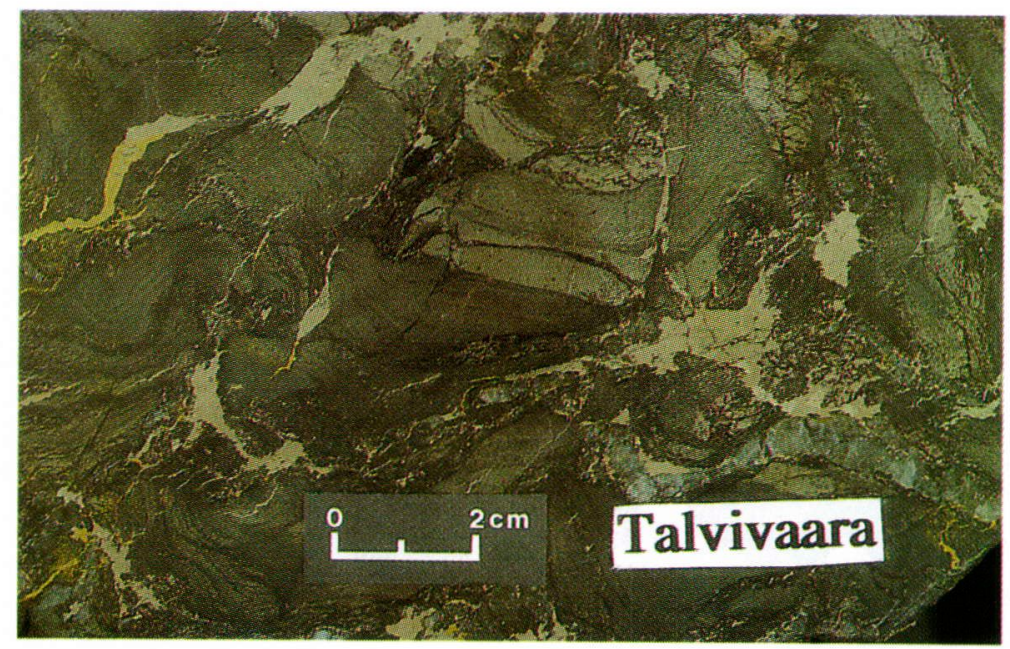

Fig. 3. Metalliferous black shale from the Talvivaara prospect (Figs. 2,4). Photo: Jari Väätäinen.

bly on the Archaean gneiss complex and consists mainly of metasediments, contains black shales interlayered with various rock assemblages (Loukola-Ruskeeniemi 1990).

The thickest formations are associated with the serpentinite - skarn—quartz rock — assemblage, 1.96-1.97 Ga in age, occurring in the Outokumpu province and the western margin of the Kainuu schist belt (Figs. 1, 2). The original thickness of black shale formations probably varied between 20 and $100 \mathrm{~m}$, depending on the site. Many of them show repetition due to tectonic processes so that the black shale formations in drill cores commonly measure $120-150 \mathrm{~m}$. The maximum thickness observed is $400 \mathrm{~m}$. In the Talvivaara area the formation is $1-2 \mathrm{~km}$ wide (Figs. 3, 4). Black shales in the Kainuu and Outokumpu areas have undergone greenschist to amphibolite facies metamorphism.

\section{Carbon, sulphur and metal concentrations in the Kainuu and Outokumpu black shales}

The black shales in the Outokumpu and Kainuu serpentinite-skarn-quartz rock - assem- blages are similar in carbon abundance: the black shales of the Outokumpu province have a median value of $7.2 \%$ (212 samples), and those of the Kainuu schist belt $7.5 \%$ (286 samples from the Alanen, Talvivaara and Jormua prospects, Fig. 2). These values are high compared with those of the average black shales described by Vine and Tourtelot (1970) and the 1.6-2.4 Ga old Aphebian shales in the Canadian Shield $(1.6 \% \mathrm{C}$, $1.37 \% \mathrm{~S}$, Cameron and Jonasson 1972). This must be because the Kainuu and Outokumpu rocks were deposited 1960-2100 million years ago in a marine environment abundant in Precambrian life forms (Loukola-Ruskeeniemi 1990). The organic material has evidently been well preserved, probably because euxinic conditions such as presently found in the Black Sea prevailed.

The average sulphur abundance of the Kainuu black shales $(8.7 \%)$ is higher than that of the Outokumpu black shales $(6.3 \%)$, mainly owing to the mineralizations in the Talvivaara area (Fig. 4). Not only the high S/C ratio but the high base metal and mercury concentrations are suggestive of hydrothermal influx (Loukola-Ruskeeniemi 1990). The ore estimate for Talvivaara indicated 

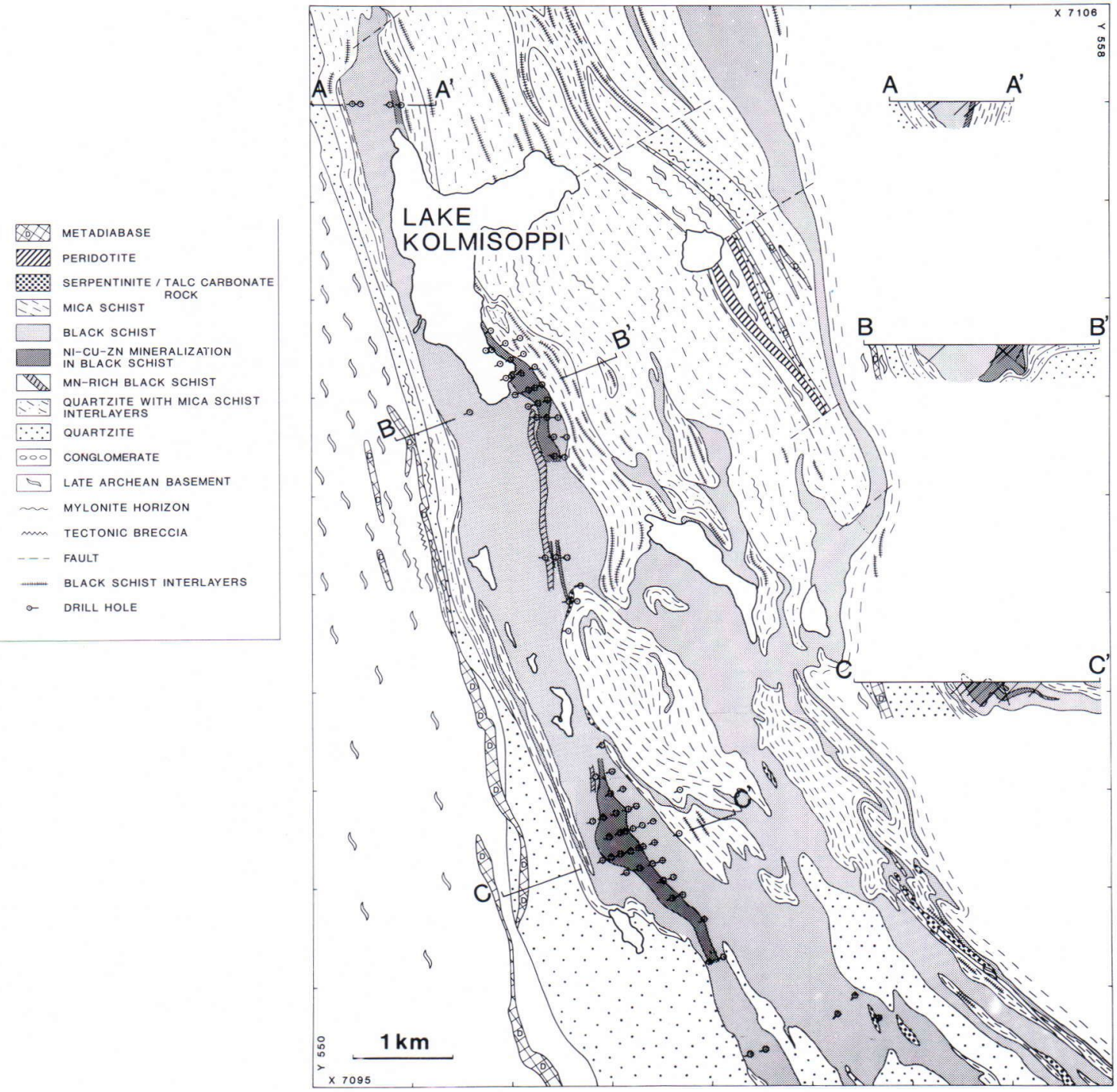

Fig. 4. Generalized geological map of the Talvivaara area (»Tal» in Fig. 2) (modified after Ervamaa and Heino 1980).

$300 \mathrm{Mt}$ of black shale containing $0.14 \% \mathrm{Cu}$, $0.26 \% \mathrm{Ni}, 0.02 \% \mathrm{Co}, 0.53 \% \mathrm{Zn}, 0.35 \% \mathrm{Mn}$, $10 \% \mathrm{Fe}, 7 \% \mathrm{C}, 630 \mathrm{ppm} \mathrm{V}, 102 \mathrm{ppm}$ Mo and $2.6 \mathrm{ppm} \mathrm{Ag}$ (Ervamaa and Heino 1980). Figure 5 shows the high ratio of sulphur to carbon and Fig. 6 gives the copper, zinc, cobalt and nickel concentrations in the black shale near lake Kolmisoppi. (Samples are the same for Fig. $7 \mathrm{C}$ and Table 1.)

\section{Mercury concentrations in Finnish black shales}

The medians of mercury concentrations in Proterozoic black shale sample sets in Finland measured in the preliminary study ranged between 0.04 and $0.18 \mathrm{ppm}$ (Ruskeeniemi et al. 1986). Concentrations were greatest in the Ostrobothnia schist belt in western Finland, where the highest value encountered was $2.6 \mathrm{ppm}$. This was 


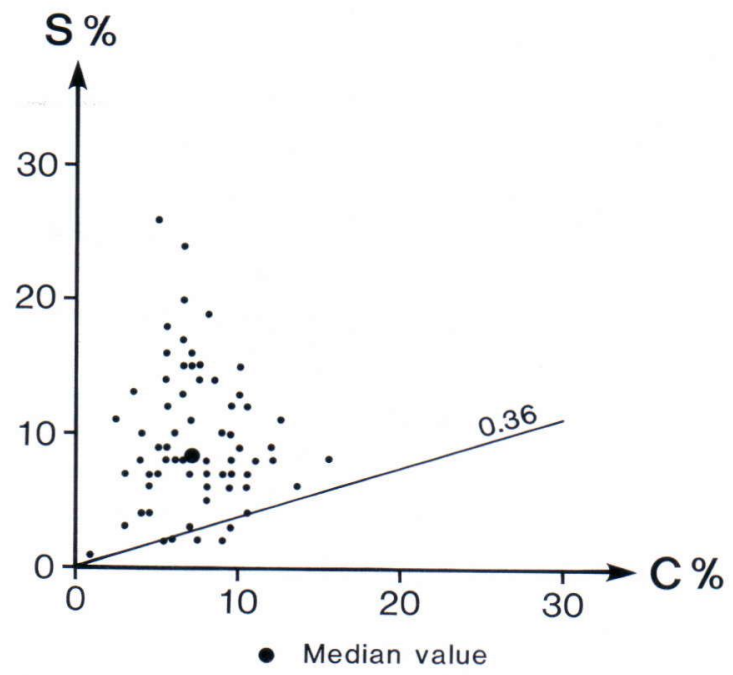

Fig. 5. Sulphur and carbon concentrations in metamorphosed black shales near lake Kolmisoppi. The $\mathrm{S} / \mathrm{C}$ ratio of the recent sediments, 0.36, is from Cameron and Garrels (1980). The median content of sulphur is $8.39 \%$ and that of carbon $7.25 \%$ (76 samples).

to be expected considering that the Vihanti zinc ore deposit, with sphalerite $(\mathrm{ZnS})$ as the main ore mineral, is located in the area, and that sphalerite may contain up to 20 mole $\% \mathrm{HgS}$ in solid solution before a co-existing mercury rich phase appears (Krupp 1988).

Concentrations of mercury in the 850 samples

Table 1. Range and mean concentrations of mercury (prospects shown in Figs. 2 and 4, Hg-Zn diagrams in Fig. 7). A value of half the detection limit has been assigned to samples with content below the limit. The mean concentration for the Aphebian shales, Canadian Shield, is from Cameron and Jonasson (1972). $\mathrm{N}=$ number of samples.

\begin{tabular}{lcccc}
\hline LOCALITY & $\begin{array}{c}\text { MIN } \\
(\mathrm{ppm})\end{array}$ & $\begin{array}{c}\text { MEAN } \\
(\mathrm{ppm})\end{array}$ & $\begin{array}{c}\text { MAX } \\
(\mathrm{ppm})\end{array}$ & $\mathrm{N}$ \\
\hline
\end{tabular}

\section{Karelian black shales}

\begin{tabular}{lrrrr} 
A) Puolanka & 0.01 & 0.22 & 0.91 & 45 \\
B) Jormua & 0.02 & 2.15 & 5.65 & 38 \\
C) Kolmisoppi & 0.01 & 1.73 & 7.47 & 76 \\
D) Kylylahti & 0.02 & 0.48 & 1.30 & 36 \\
\hline Aphebian shale & & 0.51 & & 396 \\
\hline
\end{tabular}
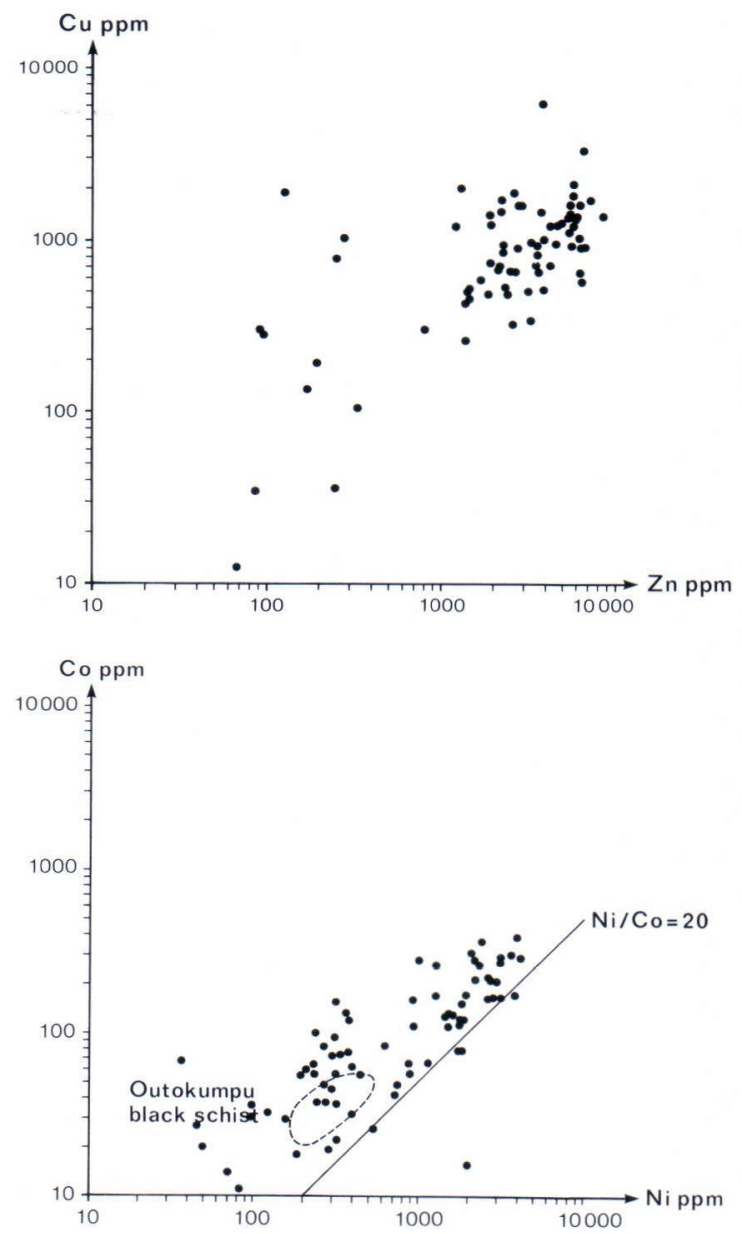

Fig. 6. Copper, zinc, cobalt and nickel concentrations in metamorphosed black shales near lake Kolmisoppi. The cobalt and nickel values of the Outokumpu black shales are after Huhma and Huhma (1970).

analysed in the present study differed from one target to another. Compared with mercury concentrations of Aphebian shales of the Canadian Shield (Cameron and Jonasson 1972), values at the Kolmisoppi and Jormua prospects are high (Table 1).

\section{Mercury concentrations in Finnish bedrock}

The average concentration of mercury in magmatic rocks in the upper continental crust is 0.03 


\section{Hg ppm}

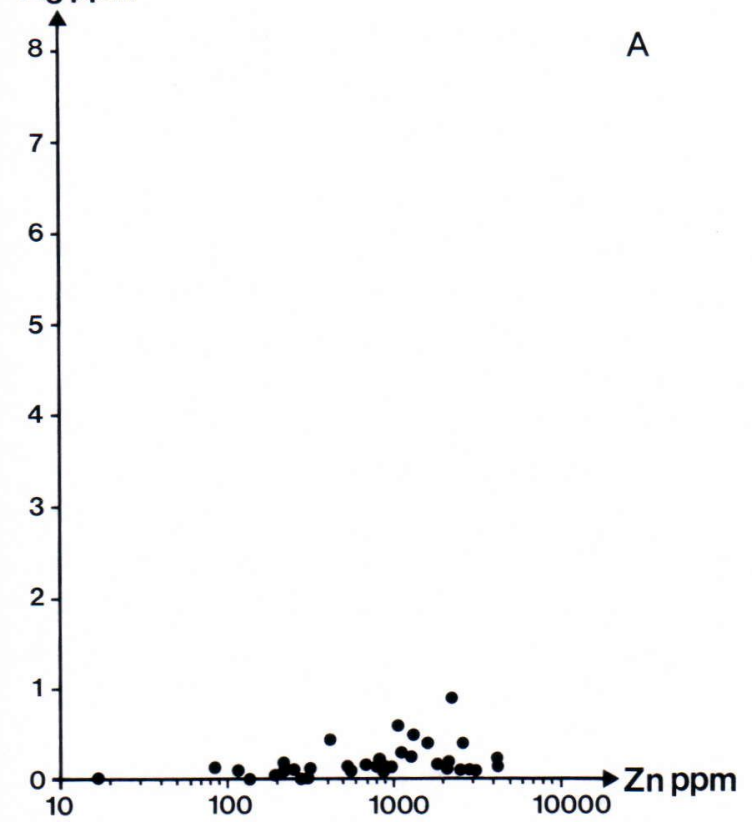

\section{$\mathrm{Hg}$ ppm}

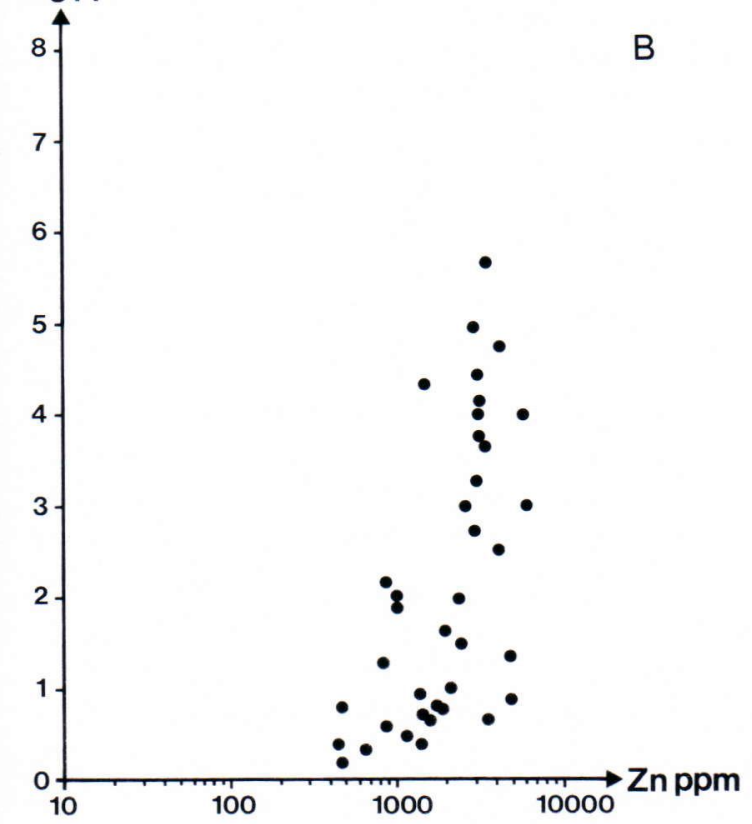

\section{Hg ppm}

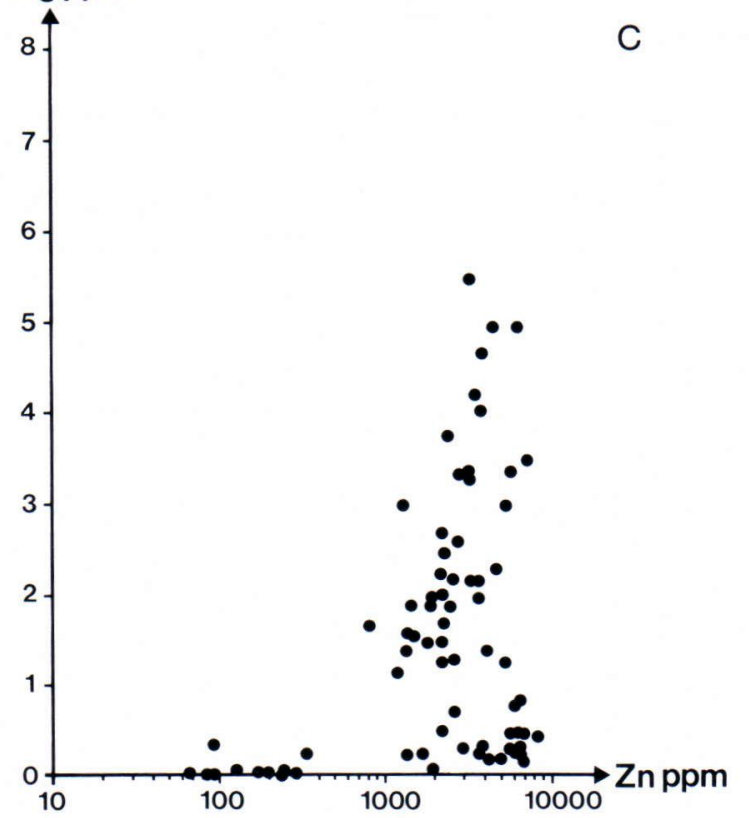

\section{Hg ppm}

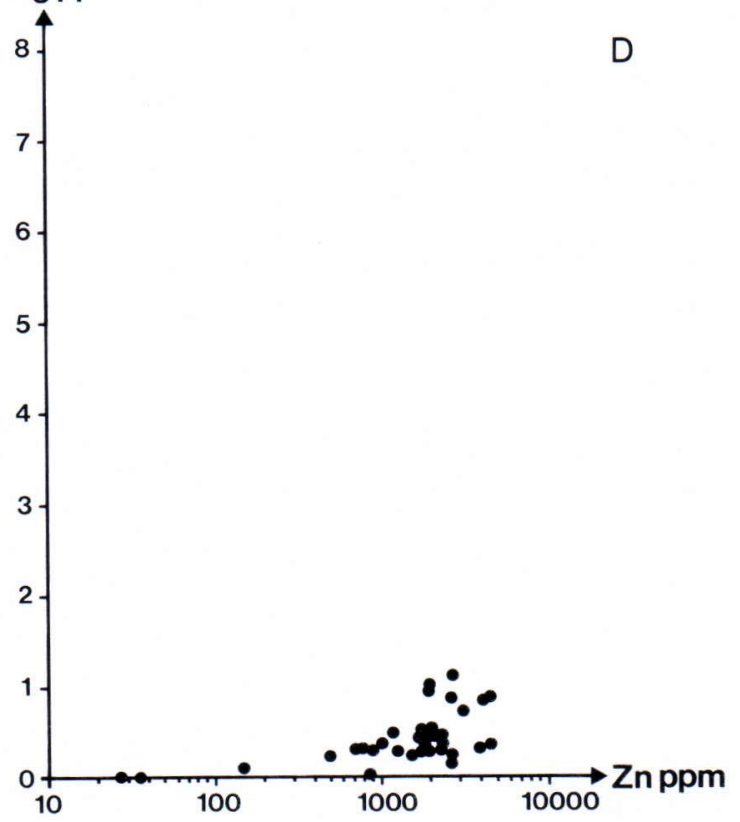

Fig. 7. Mercury and zinc concentrations in black shales A) in the Puolanka area, B) in the Jormua area, C) near lake Kolmisoppi (Fig. 4), D) at Kylylahti target in Polvijärvi (Fig. 2). 
ppm and in sedimentary rocks 0.33 ppm (Marowsky and Wedepohl 1971). In Finland, mercury concentrations of rocks other than black shales have not been studied in detail because values have been too low for the analytical methods used. For example, the mercury concentrations of rocks in the Outokumpu ore province were studied in the 1970's (Huhma 1978), but the analytical methods applied were not sensitive enough.

As a rule, mercury values are elevated only adjacent to certain kinds of ore deposits, as in the Skellefte ore district in Sweden (Widenfalk 1979). In a recent study, Nurmi et al. (1990) found a maximum of $0.58 \mathrm{ppm}$ mercury in Precambrian gold mineralizations in Finland - a low value compared with the concentrations we encountered in black shales (see Table 1).

\section{Mercury concentration in pike compared with the distribution of black shales}

Pike in lake Kolmisoppi (Esox lucius L., a large northern predatory fish) exhibit high concentrations of mercury compared with the background concentration in pike in Finnish lakes (Verta 1990). In pike in the two other lakes in Sotkamo that were studied - Jormasjärvi and

Table 2. Comparison of mercury concentrations in pike (wet weight, Verta and Rekolainen 1985) with the distribution of black shales in Sotkamo. For comparison, the mean concentration in pike in Finnish forest lakes (Verta 1990) is shown.

\begin{tabular}{|c|c|c|}
\hline LAKE & $\begin{array}{c}\mathrm{Hg} \text { in } \\
\text { pike } \\
(\mathrm{ppm})\end{array}$ & $\begin{array}{l}\text { DISTRIBUTION OF BLACK } \\
\text { SHALES }\end{array}$ \\
\hline Kolmisoppi & 0.96 & Abundant $\mathrm{Hg}$-rich black shales \\
\hline Jormasjärvi & 0.76 & $\begin{array}{l}\text { Black shale interlayers in } \\
\text { mica schist }\end{array}$ \\
\hline Älänne & 0.33 & No black shale \\
\hline
\end{tabular}

Average in

67 Finnish

forest lakes

0.56
Älänne - mercury concentrations were considerably lower. Compared with black shales in other localities, to say nothing of other rock types, the black shales in Kolmisoppi are very rich in mercury (Table 1, Fig. 7). There are a few black shale layers under lake Jormasjärvi (Havola 1981), where concentrations are slightly elevated, but none have been reported from Älänne, where concentrations are below the background. The concentrations of mercury in pike in the three lakes and the distribution of black shales are compared in Table 2.

A connection between the high mercury contents in pike and the mercury-rich black shales in the drainage area of lake Kolmisoppi is strongly indicated. Since pike in the other two lakes had very different concentrations, the anomaly cannot be attributed to atmospheric deposition from distant sources, except indirectly in the sense that acid rain enhances the weathering of black shales and thereby metal load of the lake.

A distribution of above background concentrations of mercury discovered in natural waters near Kaminak Lake in the Keewatin District, NWT, Canada, also has been linked to the underlying rocks (Hornbrook and Jonasson 1971).

\section{Summary}

In metamorphosed black shales from eastern Finland, analysed for mercury, the average mercury concentrations were well below $1 \mathrm{ppm}$. Considerably higher values were encountered for example near the Kolmisoppi and Jormua prospects in Kainuu: an average of $1.73 \mathrm{ppm}$ at Kolmisoppi and $2.15 \mathrm{ppm}$ at the Jormua ophiolite complex. Pike in lake Kolmisoppi exhibit anomalous mercury concentrations in relation to two other lakes studied in Sotkamo. As metalliferous black shale is one of the most readily weathered rocks in Finland, and mercury concentrations in the shale near Kolmisoppi are likewise anomalous, the shale is strongly indicated as the source of the mercury in the fish. 


\section{Acknowledgements}

I am grateful to professors J. Talvitie and J. Siivola for making the study possible, to R. Saikkonen, P. Väänänen and S. Peltonen for the Leco analyses and to H. Aalto, P. Jelkämäki, M. Kujala-Tammi, P. Kurki, R. Nurmi and J. Tiilikainen for the figures. I thank Dr. Kathleen

\section{References}

Cameron, E.M. \& Garrels, R.M., (1980). Geochemical compositions of some Precambrian shales from the Canadian Shield. Chem. Geol. 28: 181-197.

Cameron, E.M. \& Jonasson, I.R., (1972). Mercury in Precambrian shales of the Canadian Shield. Geochim. Cosmochim. Acta 36: 985-1005.

Ervamaa, P.\& Heino, T., (1980). A progress report on ore prospecting in the Kainuu - North Savo black shale serpentinite sequence in 1977-1979 (in Finnish). Unpubl. Rep. Geol. Surv. Finl. M19/3344/-80/1/10.

Havola, M., (1981). Geological map of Finland. 1 : 100000. Pre-Quaternary rocks. Sheet 3433 - Sotkamo. Geol. Surv. Finl.

Hornbrook, E.H.W. \& Jonasson, I.R., (1971). Mercury in permafrost regions: occurrence and distribution in the Kaminak Lake area, Northwest Territories (55L). Geol. Surv. Can., Pap. 71-43. 13 pp.

Huhma, A. \& Huhma, M., (1970). Contribution to the geology and geochemistry of the Outokumpu region. Geol. Soc. Finl. Bull. 42: 57-88.

Huhma, M., (1978). Elohopeatutkimus I ja II (in Finnish). Outokumpu Oy Unpubl. Rep.

Krupp, R., (1988). Physicochemical aspects of mercury metallogenesis. Chem. Geol. 69: 345-356.

Loukola-Ruskeeniemi, K., (1989). Early Proterozoic metamorphosed black shales in the Kainuu schist belt and in the Outokumpu region. Geol. Surv. Finl., Spec. Pap. 10: 103-106.

Loukola-Ruskeeniemi, K., (1990) Karelidien mustaliuskeiden hiili- ja rikkipitoisuudet kerrostumisympäristön kuvastajina (English summary: Carbon and sulphur abundances and carbon isotope $\delta{ }^{13} \mathrm{C}$ values in Early Proterozoic metamorphosed black shales in eastern and northern Finland). Geologi 42 No 6: 95-101.

Luukkonen, E. \& Lukkarinen, H., (1985). Stratigraphic map of Middle Finland. 1: 1000 000. Geol. Surv. Finl.
Ahonen for improving the language of the final version of the manuscript. The positive comments of Dr. W.W. Shilts of Geological Survey of Canada were most encouraging and the critical review of the manuscript by Dr. T. Koljonen was of great help. - The study was financed jointly by Academy of Finland (project 24/044) and Geological Survey of Finland.

Marowsky, G. \& Wedepohl, K.H., (1971). General trends in the behavior of $\mathrm{Cd}, \mathrm{Hg}, \mathrm{Tl}$ and $\mathrm{Bi}$ in some major rock forming processes. Geochim. Cosmochim. Acta 35: 1255-1267.

Nurmi, P.A., Lestinen, P. \& Niskavaara, H., (1990). Geochemical characteristics of mesothermal gold deposits in the Fennoscandian Shield, and a comparison with selected Canadian and Australian deposits. Geol. Surv. Finl. Bull. (in press)

Ruskeeniemi, K., Sarapää, O. \& Rehtijärvi, P., (1986). Proterotsooisten hiilipitoisten metasedimenttien kemiallisesta koostumuksesta (in Finnish). Geologi 38: 90-95.

Talvitie, J., Loukola-Ruskeeniemi, K., Heino, T. \& Vanne, $J$. , (1989). Metallogeny and geochemistry of metamorphosed black shales and serpentinites in the Kainuu schist belt, eastern Finland. Geol. Surv. Finl., Spec. Pap. 10: 101.

Verta, M., (1990). Mercury in Finnish forest lakes and reservoirs: anthropogenic contribution to the load and accumulation in fish. Publ. Water Environ. Res. Inst. Natl Board of Waters and the Environment, Finland, No. 6. 34 pp.

Verta, M. and Rekolainen, S., (1985). Ilmaperäisen elohopean, metsäojituksen ja tekojärvien rakentamisen vaikutus kalojen elohopeapitoisuuteen (in Finnish). Tutkimusprojektin loppuraportti. Vesihallituksen monistesarja Nro 320.

Vine, J. \& Tourtelot, E., (1970). Geochemistry of Black Shale Deposits - A Summary Report. Econ. Geol. 65: $253-272$.

Widenfalk, L., (1979). Mercury as an indicator of stratigraphy and metamorphism in the Skellefte ore district. Econ. Geol. 74: 1307-1314.

Received June 30, 1990

Revision accepted October 31, 1990 